\title{
Effect of the production year and artificial fertilization on the yield and protein content of Renfor (FAO 320) maize hybrid
}

\author{
Éva HORVÁTH - Péter FEJÉR - Adrienn SZÉLES \\ Institute for Land Utilisation, Regional Development and Technology, Faculty of Agricultural and Food Sciences \\ and Environmental Management, University of Debrecen; E-mail: horvath.eva@agr.unideb.hu
}

Keywords: climate change, maize, yield, protein

\section{Introduction}

The productivity of crop production and maize production largely influence the security of food supply as a whole. Therefore the most important objective is to avoid or reduce yield loss - which may exceed $20 \%$ in most parts of Europe - and quality deterioration resulting from weather extremes that are caused by climate change and to prevent or reduce quality deterioration ( Campos et al., 2004; Kang et al., 2009; Veisz, 2009; Laux et al., 2010). Adequate nutrient supply ensures high yield (Nagy 2017; Pepó 2017) and contributes to the increased protein content of maize grain and its improved quality (Bokori et al., 2003; Izsáki, 2009).

\section{Materials and methods}

Our examinations were conducted in Hungary at the Látókép Experimental Station of the University of Debrecen ( $47^{\circ} 33$ ' $\mathrm{S}, 21^{\circ} 26^{\prime} \mathrm{E}$, height $\left.111 \mathrm{~m}\right)$. The soil type of the trial was loess formed, deep humus layered limestone chernozem soil (Mollisol-Calciustoll or Vermustoll, clayey loam, USDA). The trial is a strip distributed small-plot field trial Measurements were carried out in average (2017) and dry (2018) years with the involvement of the Renfor (FAO 320) maize hybrid. In the scope of the trial, $60 \mathrm{~kg}$ and $120 \mathrm{~kg}$ of $\mathrm{N} \mathrm{ha}^{-1}$ were applied in addition to the fertilization-free treatment (control) as spring base fertilizers followed by two additional fertilization treatments in V6 and V12 phenophases with a volume of +30 and $+30 \mathrm{~kg} \mathrm{~N} \mathrm{ha}^{-1}$. Correlation between the cultivation factor (fertilizer, production year) and the dependent variable (protein content, yield) was assessed by means of a general linear model (GLM). Comparison of yield and its mean values was carried out by means of a Duncan test. Evaluation was done with the SPSS for Windows 21.0 statistical software package.

\section{Results and discussion}

In the production year of 2017 , the lowest yield was recorded in the case of the nonfertilized treatment $\left(8.17 \mathrm{t} \mathrm{ha}^{-1}\right)$. Yield measured for the $60 \mathrm{~kg} \mathrm{~N}^{-1}$ basic treatment showed a $34.7 \%$ increase $(\mathrm{p}<0.05)$ as compared to the non-fertilized treatment. Increasing the $\mathrm{A}_{120}$ basic treatment with $30 \mathrm{~kg} \mathrm{~N} \mathrm{ha}^{-1}\left(\mathrm{~V}_{150}\right)$ during the $\mathrm{V} 6$ phenophase, the additional yield was $2.62 \mathrm{t} \mathrm{ha}^{-1}$, which is not statistically verified. Difference between the 60 and 120 $\mathrm{kg} \mathrm{N} \mathrm{ha}^{-1}$ basic treatments and the additionally applied $\mathrm{N}$ dose during the V12 phenophase did not show any significant difference. During the dry production year (2018) the lowest yield was again recoded in the case of the non-fertilized treatment $\left(7.33 \mathrm{t} \mathrm{ha}^{-1}\right)$. The basic treatment of $60 \mathrm{~kg} \mathrm{~N}^{-1}$ resulted in a $45.6 \%(\mathrm{p}<0.05)$ yield increase, however the application of additional $+30+30 \mathrm{~kg} \mathrm{~N} \mathrm{ha}^{-1}$ during the $\mathrm{V} 6$ and $\mathrm{V} 12$ phenophases following 
the $60 \mathrm{~kg} \mathrm{~N} \mathrm{ha}^{-1}$ basic fertilizer dose did not have a significant effect on the amount of yield. The difference between the $\mathrm{A}_{60}$ and $\mathrm{A}_{120}$ treatments is statistically not verified. Increase of the $\mathrm{A}_{120}$ treatment with a $+30 \mathrm{~kg} \mathrm{~N} \mathrm{ha}^{-1}$ dose $(15.8 \%)$, and another $30 \mathrm{~kg} \mathrm{~N} \mathrm{ha}^{-1}$ during the V12 phenophase (11.6\%) resulted in additional yield. The significantly verified highest yield was recorded in 2017 with $30 \mathrm{~kg} \mathrm{~N} \mathrm{ha}^{-1}$ basic treatment $\left(11.02 \mathrm{t} \mathrm{ha}^{-1}\right)$, and in 2018 with V12 ${ }_{180} \mathrm{~kg} \mathrm{~N} \mathrm{ha}^{-1}\left(13.38 \mathrm{tha}^{-1}\right)$ treatment.

Depending on the fertilizer treatments and the production year, protein content of the Renfor hybrid varied between 7.0-9.9 $\mathrm{g} \mathrm{x} 100 \mathrm{~g}^{-1}$. The highest statistically verifiable protein content was recorded in 2017 with the $\mathrm{V} 12_{180}\left(9.9 \mathrm{~g} \mathrm{x} 100 \mathrm{~g} \mathrm{~g}^{-1}\right)$ treatment and in

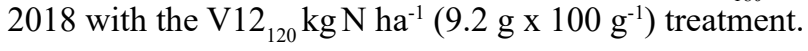

\section{Conclusions}

Overall, it can be established that the effect of production year $(p<0.05)$ and fertilizer treatments $(p<0.001)$ on grain yield was significant. Production year did not have any effect on the protein content, while the influence of fertilizer treatments $(p<0.001)$ was detectable. There was a positive correlation between yield and protein content in both years. Protein content was affected by yield at $79.6 \%$ in 2017 and $69.3 \%$ in 2018 . This correlation was close in both years $(r=0.892, r=0.832)$.

\section{Acknowledgement}

The research was financed by the Higher Education Institutional Excellence Programme of the Ministry of Human Capacities in Hungary, within the framework of the 4.thematic programme of the University of Debrecen, and the projects "GINOP-2.2.1-15-2016-00001

- Developing a scale-independent complex precision consultancy system" and "EFOP3.6.3-VEKOP-16-2017-00008".

\section{References}

Bokori J., Gundel J., Herold I., Kakuk T., Kovács G., Mézes M., Schmidt J., Szigeti G., Vincze L. (2003): A takarmányozás alapjai. Mezőgazda Kiadó, Budapest.

Campos H., Cooper M. Habben J.E., Edmeades G.O., Schussler J.R. (2004): Improving drought tolerance in maize a view from industry. Field Crops Research. 90: 1.19-34. https://doi.org/10.1016/j.fcr.2004.07.003

Izsáki Z. (2009): Effect of nitrogen supply on nutritional of maize. Communications in Soil Science and Plant Analysis. 40: 960-973. https://doi.org/10.1080/00103620802693482

Kang Y., Khan S., Ma X. (2009): Climate change impacts on crop yield, crop water productivity and food security - A review. Progress in Natural Science. 19: 1665-1674. https://doi.org/10.1016/j.pnsc.2009.08.001

Laux, P., Jäckel, G., Tingem, R. M., Kunstmann, H. (2010): Impact of climate change on agricultural productivity under rainfed conditions in Cameroon - A method to improve attainable crop yields by planting date adaptations. Agricultural and Forest Meteorology. 150: 9. 1258-1271. https://doi.org/10.1016/j. agrformet.2010.05.008

Nagy J. (2017): Klímaváltozás és a mütrágyázás hatása a kukorica termésére debreceni tartamkísérletben. Növénytermelés. 66: 3. 11-32.

Pepó P. (2017): Tartamkísérletek mint a klímaváltozás indikátorai. Növénytermelés. 66: 3. 33-45.

Veisz O. (2009): Martonvásári regionális kutatási és képzési központ. In: Veisz, O. (szerk.) A martonvásári agrárkutatások hatodik évtizede. 1999-2009. MTA Mezőgazdasági Kutatóintézet, Martonvásár, 9-14. 